\title{
Matrix Metalloproteinase-9 Contributes to Kindled Seizure Development in Pentylenetetrazole-Treated Mice by Converting Pro-BDNF to Mature BDNF in the Hippocampus
}

\author{
Hiroyuki Mizoguchi, ${ }^{1,2}$ Junya Nakade, ${ }^{2}$ Masaki Tachibana, ${ }^{2}$ Daisuke Ibi, ${ }^{2,3}$ Eiichi Someya, ${ }^{3}$ Hiroyuki Koike, ${ }^{2}$ \\ Hiroyuki Kamei, ${ }^{4}$ Toshitaka Nabeshima, ${ }^{5}$ Shigeyoshi Itohara, ${ }^{6}$ Kazuhiro Takuma, ${ }^{2}$ Makoto Sawada, ${ }^{7}$ Jun Sato, ${ }^{1}$ \\ and Kiyofumi Yamada ${ }^{2,3}$ \\ ${ }^{1}$ Futuristic Environmental Simulation Center, Research Institute of Environmental Medicine, Nagoya University, Nagoya 464-8601, Japan, ${ }^{2}$ Laboratory of \\ Neuropsychopharmacology, Division of Life Sciences, Graduate School of Natural Science and Technology, Kanazawa University, Kanazawa 920-1192, \\ Japan, ${ }^{3}$ Department of Neuropsychopharmacology and Hospital Pharmacy, Nagoya University Graduate School of Medicine, Nagoya 466-8560, Japan, \\ ${ }^{4}$ Division of Clinical Science in Clinical Pharmacy Practice, Management and Research, Faculty of Pharmacy, Meijo University, Nagoya 466-8503, Japan, \\ ${ }^{5}$ Department of Chemical Pharmacology, Graduate School of Pharmaceutical Sciences, Meijo University, Nagoya 466-8503, Japan, ${ }^{6}$ Laboratory for \\ Behavioral Genetics, RIKEN Brain Science Institute, Wako 351-0198, Japan, and 'Department of Brain Functions, Division of Stress Adaptation and \\ Protection, Research Institute of Environmental Medicine, Nagoya University, Nagoya, 464-8601, Japan
}

Recurrent seizure activity has been shown to induce a variety of permanent structural changes in the brain. Matrix metalloproteinases (MMPs) function to promote neuronal plasticity, primarily through cleavage of extracellular matrix proteins. Here, we investigated the role of MMP-9 in the development of pentylenetetrazole (PTZ)-induced kindled seizure in mice. Repeated treatment with PTZ (40 mg/kg) produced kindled seizure, which was accompanied by enhanced MMP- 9 activity and expression in the hippocampus. No change in MMP-9 activity was observed in the hippocampi of mice with generalized tonic seizure following single administration of PTZ (60 mg/kg). MMP-9 colocalized with the neuronal marker NeuN and the glial marker GFAP in the dentate gyrus of the kindled mouse hippocampus. Coadministration of diazepam or MK-801 with PTZ inhibited the development of kindling and the increased MMP-9 levels in the hippocampus. Marked suppression of kindled seizure progression in response to repeated PTZ treatment was observed in MMP-9 ${ }^{(-1-)}$ mice compared with wild-type mice, an observation that was accompanied by decreased hippocampal levels of mature brain-derived neurotrophic factor. Microinjecting the BDNF scavenger TrkB-Fc into the right ventricle before each PTZ treatment significantly suppressed the development of kindling in wild-type mice, whereas no effect was observed in MMP- $9^{(-l-)}$ mice. On the other hand, bilateral injections of pro-BDNF into the hippocampal dentate gyrus significantly enhanced kindling in wild-type mice but not MMP- $9^{(-1-)}$ mice. These findings suggest that MMP-9 is involved in the progression of behavioral phenotypes in kindled mice because of conversion of pro-BDNF to mature BDNF in the hippocampus.

\section{Introduction}

Seizures cause brain injury via a number of mechanisms, potentially contributing to neurologic and cognitive deficits in epilepsy patients. Although seizures induce neuronal death in some situ-

Received June 20, 2011; revised July 22, 2011; accepted July 22, 2011.

Author contributions: H.M. and K.Y. designed research; H.M., J.N., and M.T. performed research; H.M., T.N., S.I., and K.Y. contributed unpublished reagents/analytic tools; H.M., J.N., M.T., D.I., E.S., H. Koike, H. Kamei, T.N., K.T., M.S., J.S., and K.Y. analyzed data; H.M. and K.Y. wrote the paper.

This study was supported in part by Grants-in-aid for Scientific Research 21790068, 22390046, 23790082, and 23659135 from the Japan Society for the Promotion of Science; a grant from the Japan Epilepsy Research Foundation; a grant from Kowa Life Science Foundation; a grant from the Nakatomi Foundation; the Program for Promotion of Fundamental Studies in Health Sciences from the National Institute of Biomedical Innovation; grants for the global COE program from the Ministry of Education, Culture, Sports, Science and Technology of Japan and the Academic Frontier Project for Private Universities; and a matching fund subsidy from the Ministry of Education, Culture, Sports, Science and Technology, 2007-2011.

The authors declare no competing financial interests.

Correspondence should be addressed to Dr. Kiyofumi Yamada, Department of Neuropsychopharmacology and Hospital Pharmacy, Nagoya University Graduate School of Medicine, Showa-ku, Nagoya 466-8560, Japan. E-mail: kyamada@med.nagoya-u.ac.jp.

DOI:10.1523/JNEUROSCI.3118-11.2011

Copyright $\odot 2011$ the authors $\quad 0270-6474 / 11 / 3112963-09 \$ 15.00 / 0$ ations, they also can produce nonlethal pathophysiologic effects on neuronal structures and functions (Zeng et al., 2007). Kindling is an experimental epilepsy model in which repeated electrical or chemical stimulation of certain forebrain structures triggers progressively more intense electroencephalographic and behavioral seizure activity (Goddard et al., 1969; Racine, 1972). Once established, kindling results in a permanent state of seizure susceptibility, which may manifest as spontaneous epileptiform seizures (Pinel and Rovner, 1978). Kindling has recently been shown to induce a variety of permanent structural changes in the brain, including sprouting of the mossy fiber pathway that originates from hippocampal dentate gyrus (DG) granule cells (Sutula et al., 1988; Cavazos et al., 1991) and neuronal loss in the hippocampus (Cavazos et al., 1994).

Matrix metalloproteinases (MMPs) function to remodel the pericellular environment, primarily through cleavage of extracellular matrix proteins and cell surface components (Yong et al., 2001). Gelatinases (MMP-2 and MMP-9), for example, cleave the cell adhesion proteins collagen IV and V, laminin, and chondroi- 
tin sulfate proteoglycan (Yong et al., 2001). Of clinical relevance, MMP-9 has been implicated in amyloid-induced cognitive impairment and neurotoxicity (Mizoguchi et al., 2009), cerebral ischemia, kainate-induced neuronal injury (Szklarczyk et al., 2002), hippocampal long-term potentiation and memory (Nagy et al., 2006), and methamphetamine dependence (Mizoguchi et al., 2007a, 2007b). Thus, MMP-9 is involved in neuronal activitydependent synaptic plasticity and cell death in the brain.

Interestingly, serum MMP-9 levels and the ratio of MMP-9 to tissue inhibitor of metalloproteinase- 1 are elevated in children with various febrile seizures and convulsive status epilepticus (Suenaga et al., 2008). Moreover, expression of MMP-9 mRNA increases in response to neuronal depolarization in the rat hippocampus (Rylski et al., 2009). After seizure, MMP-9 mRNA is transported to dendrites and synapses in the hippocampal DG of kainic acid-treated rats (Konopacki et al., 2007). Jourquin et al. (2003) used organotypic cultures to demonstrate increased release and activity of MMP-9 after stimulation with neurotoxic kainate and reduced neuronal cell death following MMP-9 inhibition. Although MMP-9 is expressed in response to neural activity in some models of epileptogenesis (Wilczynski et al., 2008; Kim et al., 2009; Takács et al., 2010), the pathophysiologic and etiologic roles of this metalloproteinase, including potential molecular targets, during kindling seizure development have not been elucidated. In the present study, we used MMP-9 homozygous knock-out (MMP-9 $\left.{ }^{(-/)}\right)$mice to investigate the role of MMP-9 in kindling induced by pentylenetetrazole (PTZ).

\section{Materials and Methods}

Animals. Male ICR mice (7-8 weeks old; weighing $40 \pm 5 \mathrm{~g}$ at the beginning of the experiments) were obtained from CLEA Japan. We also used MMP-9 ${ }^{(-1-)}$ (Jackson Laboratory), MMP-2 homozygous knock-out $\left(\mathrm{MMP}^{-2^{(-/-)}}\right.$) (Itoh et al., 1997), and wild-type (C57BL/6J) mice (9-14 weeks old). The mutant mice were backcrossed into the C57BL/6J strain $>13$ times. Mutant and wild-type mice used in the present study were littermates, and only male mice were used in the behavioral tests. The animals were housed in plastic cages and kept in a regulated environment $\left(23 \pm 1^{\circ} \mathrm{C} ; 50 \pm 5 \%\right.$ humidity) with a $12 \mathrm{~h}$ light-dark cycle (lights on at 9:00 A.M.). Food (CE-2, CLEA Japan) and tap water were available ad libitum. All experiments were performed in accordance with the Guidelines for Animal Experiments of Kanazawa University and Nagoya University Graduate School of Medicine, the Guiding Principles for the Care and Use of Laboratory Animals approved by the Japanese Pharmacological Society, and the United States National Institutes of Health Guide for the Care and Use of Laboratory Animals.

Drugs. PTZ (Sigma-Aldrich) and dizocilpine hydrogen maleate (MK801; Sigma-Aldrich) were dissolved in saline. Diazepam (Sigma-Aldrich) was suspended in $1 \%$ carboxymethyl cellulose (CMC).

Seizure observation and kindling procedure. PTZ was administered intraperitoneally at a dose of $20-60 \mathrm{mg} / \mathrm{kg}$. We used the PTZ-induced kindling model described by Schröder et al. (1993) and Becker et al. (1995). ICR mice were intraperitoneally injected with PTZ (40 mg/kg) once every $48 \mathrm{~h}$ for at least nine total injections, and mice showing more than three consecutive Stage 4 seizures were used as kindled mice. Because of their different sensitivity to PTZ, C57BL/6J mice were injected with PTZ at a dose of $35 \mathrm{mg} / \mathrm{kg}$ to induce kindling. The PTZ dose was reduced to $25 \mathrm{mg} / \mathrm{kg}$ for mice in which guide cannulae had been implanted for intraventricular or intrahippocampal microinjections (see below). Control animals were injected with saline. Diazepam $(1 \mathrm{mg} / \mathrm{kg})$ or MK-801 $(0.1 \mathrm{mg} / \mathrm{kg})$ was administered intraperitoneally $30 \mathrm{~min}$ before PTZ injection. We examined seizure events during a $20 \mathrm{~min}$ observation period after each stimulation.

The seizure intensity was scored as follows (Schröder et al., 1993; Becker et al., 1995, modified): Stage 0, no response; Stage 1, ear and facial twitching; Stage 2, convulsive twitching axially through the body; Stage 3, myoclonic jerks and rearing; Stage 4, turning over onto the side, wild
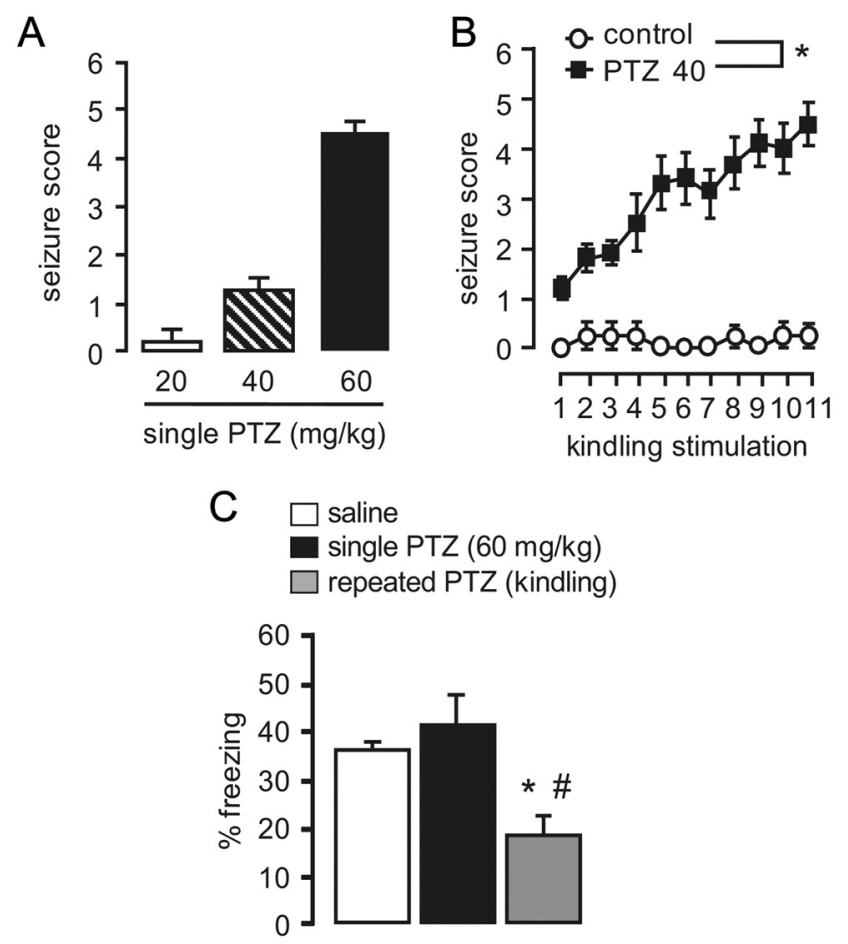

Figure 1. Seizure and kindling evoked by treating mice once $(\boldsymbol{A})$ or repeatedly $(\boldsymbol{B})$ with PTZ. $A$, Mice received a single injection of $P T Z$ at a dose of 20,40, or $60 \mathrm{mg} / \mathrm{kg}$. Values are means \pm $\mathrm{SE}(n=4-6) \cdot \boldsymbol{B}$, Mice were administered PTZ 11 times at a dose of $40 \mathrm{mg} / \mathrm{kg} .{ }^{*} p<0.05$ versus control group. Values are means $\pm \mathrm{SE}(n=4-10)$. C, Hippocampus-dependent fear memory in control mice treated with saline, mice treated with a single dose of PTZ $(60 \mathrm{mg} / \mathrm{kg})$, and kindled mice treated repeatedly with PTZ (40 mg/kg). Context-dependent freezing was measured $24 \mathrm{~h}$ after training in a conditioned fear-learning test. Values are means \pm SE $(n=$ $8-10) .{ }^{*} p<0.05$ versus saline-treated mice. ${ }^{\#} p<0.05$ versus single PTZ dose $(60 \mathrm{mg} / \mathrm{kg})$.

running, and wild jumping; Stage 5, generalized tonic-clonic seizures; and Stage 6, death.

Microinjection of tropomyosin-related kinase $B-F c$ and pro-brainderived neurotrophic factor. Mice were anesthetized with sodium pentobarbital and placed in a stereotaxic apparatus. Metal guide cannulae (inner diameter, $0.4 \mathrm{~mm}$; outer diameter, $0.5 \mathrm{~mm}$ ) were implanted stereotaxically into the right ventricle (anteroposterior -0.3 ; mediolateral +1.0 from the bregma; dorsoventral -2.2 from the skull) for injections of the brain-derived neurotrophic factor (BDNF) scavenger tropomyosinrelated kinase B-Fc (TrkB-Fc), and bilaterally into the DG of the hippocampus (anteroposterior -2.2 ; mediolateral \pm 1.2 from the bregma; dorsoventral -1.8 from the skull) for injections of pro-BDNF. The guide cannula was mounted on the skull with dental cement, and a dummy cannula was left in place throughout the experiment. Mice were allowed to recover for $4 \mathrm{~d}$. On Day 5, a 28-G infusion cannula was inserted through the guide cannula until it protruded $0.5 \mathrm{~mm}$ beyond the inner end. TrkB-Fc (R\&D Systems) or IgG $\mathrm{G}_{1}$-Fc (R\&D Systems) was microinjected at a dose of $50 \mathrm{ng} / \mu \mathrm{l}$ and a rate of $1 \mu \mathrm{l} / \mathrm{min}$ (final volume, $2 \mu \mathrm{l}$ ) according to previous reports (Yajima et al., 2005; Zhou et al., 2010) with minor modifications. pro-BDNF (50 ng/ $\mu \mathrm{l}$; \#B-240, Alomone Labs) or the vehicle PBS was bilaterally microinjected at a rate of $1 \mu \mathrm{l} / \mathrm{min}$ (final volume, $1 \mu \mathrm{l}$ ) according to the previous studies (Shirayama et al., 2002; Yajima et al., 2005) with minor modifications. After the injection, the cannula was left in place for $1 \mathrm{~min}$ to allow the solution to diffuse. PTZ $(25 \mathrm{mg} / \mathrm{kg}$ ) was injected $30 \mathrm{~min}$ after microinjection of the drugs.

Conditioned fear memory test. Contextual fear conditioning tests were performed based on previous reports (Mizoguchi et al., 2010) with minor modifications. Freezing behavior, during which the mouse's head, arms, and legs did not move, was timed using a stopwatch. To measure the basal freezing response (preconditioning phase), mice were individually placed in a transparent Plexiglas conditioning cage $(30 \times 30 \times 35 \mathrm{~cm})$ for 2 min. For training (conditioning phase), mice were placed in the con- 
A
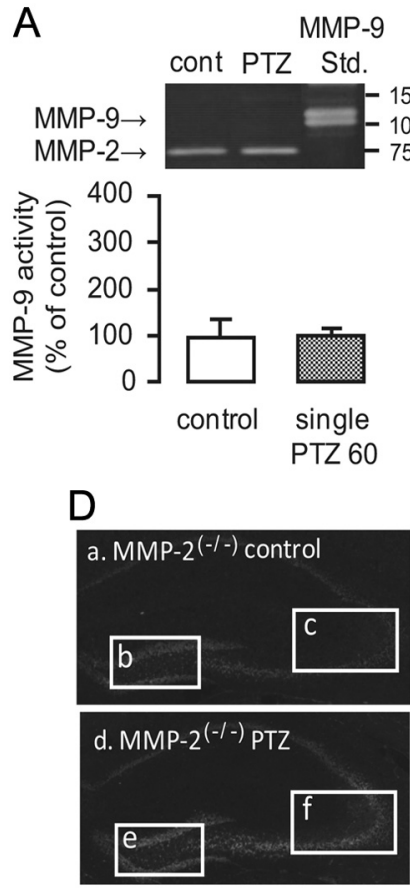

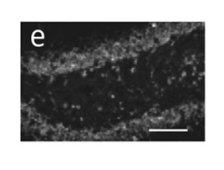

B

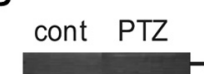

C
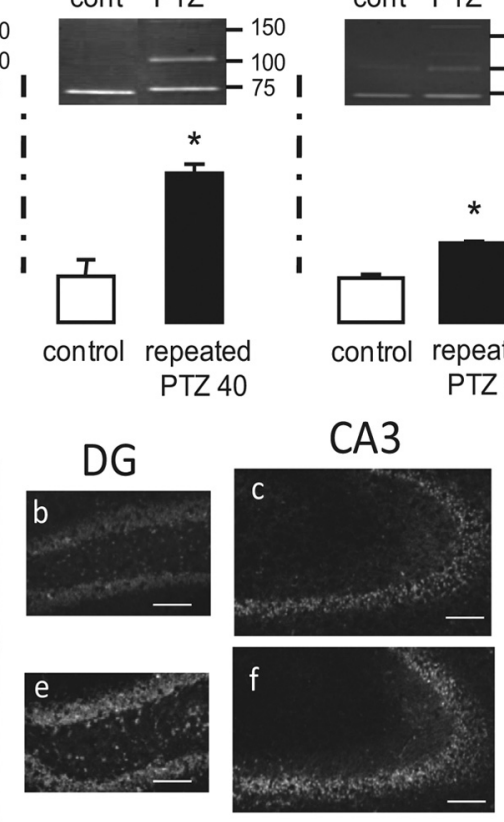

Figure 2. MMP-9 activity in the hippocampi of mice after single $(\boldsymbol{A})$ or repeated $(\boldsymbol{B}, \boldsymbol{C})$ doses of PTZ. $\boldsymbol{A}$, Mice were administered PTZ at a dose of $60 \mathrm{mg} / \mathrm{kg}$ and killed $2 \mathrm{~h}$ later. Control (Cont) mice were administered saline. MMP-9 standard (MMP-9 Std.) was used as a positive control. Values are means $\pm \mathrm{SE}(n=4) . B, C$, Mice were administered PTZ at least 11 times at a dose of $40 \mathrm{mg} / \mathrm{kg}$ and killed $2 \mathrm{~h}(\boldsymbol{B})$ or $24 \mathrm{~h}(\boldsymbol{C})$ after the final dose. Values are means $\pm \mathrm{SE}(n=7$ for $\boldsymbol{B} ; n=4$ for $\boldsymbol{C}$. D, In situ zymography detected gelatinase (MMP-9) activity in the mouse hippocampus after repeated PTZ treatment. MMP-2 ${ }^{(-1-)}$ mice were administered saline $(\boldsymbol{a}-\boldsymbol{c})$ or PTZ $(\boldsymbol{d}-\boldsymbol{f})$ at least 11 times at a dose of $40 \mathrm{mg} / \mathrm{kg}$ and killed $2 \mathrm{~h}$ after the final dose. Brain sections were incubated with fluorescent gelatin. Cleavage of gelatin by proteinases resulted in increased fluorescence. Scale bar, $100 \mu \mathrm{m}$.

ditioning cage and subjected to the conditioned stimulus ( $15 \mathrm{~s}$ tone at 80 $\mathrm{dB}$ ). During the last $5 \mathrm{~s}$ of the tone stimulus, a $0.8 \mathrm{~mA}$ foot shock was delivered as the unconditioned stimulus via a shock generator (BrainScience Idea). This procedure was repeated four times with $15 \mathrm{~s}$ intervals. Contextual tests were performed $1 \mathrm{~d}$ after fear conditioning. For the contextual test, mice were placed in the conditioning cage and the freezing response was measured for $2 \mathrm{~min}$ in the absence of the conditioned stimulus.

Quantitative analysis of BDNF $m R N A$. After the final administration of PTZ, mice were decapitated. A region of the brain that included the hippocampus was dissected from freshly perfused brains, immediately frozen, and stored at $-80^{\circ} \mathrm{C}$ until the assay. All dissections were performed using brain matrix (BrainScience Idea) and based on an anatomic atlas (Franklin and Paxinos, 1997).

Sequences of the forward and reverse primers used for the real-time PCRs are as follows: mouse BDNF, 5' ${ }^{\prime}$ TAAATGAAGTTTATACAGTACAGTGG TTCTACA- $3^{\prime}$ and $5^{\prime}$-AGTTGTGCGCAAATGACTGTTT- ${ }^{\prime}$; and mouse GAPDH, $5^{\prime}$-TGTCAAGCTCATTTCCTGGTATGA- ${ }^{\prime}$ and $5^{\prime}$-CTTACTCC TTGGAGGCCATGTAG-3'. cDNA was synthesized from total RNA (Qiagen) using reverse transcriptase and a Superscript III kit (Invitrogen). The cDNA was synthesized from $1 \mu \mathrm{g}$ of total RNA. To standardize the reactions, GAPDH was amplified simultaneously. The change in reporter fluorescence in each reaction tube was monitored with an ABI 7300 Fast Real-Time PCR System (Applied Biosystems).

Gel zymography. Samples were prepared as described previously (Zhang and Gottschall, 1997; Mizoguchi et al., 2007a, 2007b). Briefly, brain tissues were homogenized in lysis buffer $(50 \mathrm{~mm}$ Tris- $\mathrm{HCl}$ at $\mathrm{pH}$ 7.6, $150 \mathrm{~mm} \mathrm{NaCl}, 5 \mathrm{~mm} \mathrm{CaCl}_{2}, 0.05 \%$ Briji 35, and $0.02 \% \mathrm{NaN}_{3}$ ) with $1 \%$ Triton X-100 and centrifuged at $12,000 \times g$ for 10 min to pellet insoluble materials. The protein concentration in the supernatant was determined using a Protein Assay Rapid Kit (Bio-Rad). The supernatant was incubated with gelatin-Sepharose 4B (GE Healthcare Biosciences), which had been previously washed three times with lysis buffer. The samples were subjected to constant shaking for $24 \mathrm{~h}$ at $4^{\circ} \mathrm{C}$. After centrif- ugation at $500 \times g$ for $2 \mathrm{~min}$, the pellet was resuspended in $500 \mu \mathrm{l}$ of lysis buffer and washed three times. The pellet was resuspended in $150 \mu$ l of lysis buffer containing 10\% dimethyl sulfoxide, shaken for $2 \mathrm{~h}$, and used for assaying the gelatinase activities of MMP-2 and MMP-9.

The samples were subjected to electrophoresis in $10 \%$ SDS-polyacrylamide gels containing $0.1 \%$ gelatin under nonreducing conditions. Gels were washed twice for $30 \mathrm{~min}$ in $2.5 \%$ Triton X-100 to remove SDS, washed for 30 $\mathrm{min}$ in incubation buffer $(50 \mathrm{~mm}$ Tris- $\mathrm{HCl}$ at $\mathrm{pH}$ 7.4, $5 \mathrm{~mm} \mathrm{CaCl}_{2}, 2 \mu \mathrm{M} \mathrm{ZnCl}_{2}, 200 \mathrm{~mm} \mathrm{NaCl}$, and $0.02 \%$ Briji 35 ) at $25 \pm 2^{\circ} \mathrm{C}$, and further incubated for $24 \mathrm{~h}$ in the same buffer at $37^{\circ} \mathrm{C}$. Gels were then stained for $3 \mathrm{~h}$ in Coomassie Blue (1\% Coomassie Brilliant Blue G-250, 30\% methanol, and $10 \%$ acetic acid) and destained in $40 \%$ methanol $/ 7 \%$ acetic acid until clear bands of gelatinolysis appeared on the dark background. Total activity including proMMP was analyzed with an ATTO Densitograph Software Library Lane Analyzer (Atto Instruments).

Western blotting. ECM proteins were examined by Western blotting as described previously (Mizoguchi et al., 2004). Protein concentrations were determined using a Protein Assay Rapid Kit (Wako Pure Chemicals). Tissue samples from the hippocampus were homogenized at $4^{\circ} \mathrm{C}$ in lysis buffer composed of $20 \mathrm{~mm}$ Tris- $\mathrm{HCl}$ (pH 7.4), $150 \mathrm{~mm} \mathrm{NaCl}, 50$ mм NaF, 1 mм EDTA, 1 mм EGTA, 1\% Triton $\mathrm{X}-100,1 \mathrm{~mm}$ sodium orthovanadate, $0.1 \%$ SDS, $1 \%$ sodium deoxycholate, $0.5 \mathrm{~mm}$ dithiothreitol, 10 mu sodium pyrophosphate decahydrate, 1 mм phenylmethylsulfonyl fluoride, $10 \mu \mathrm{g} / \mathrm{ml}$ aprotinin, $10 \mu \mathrm{g} / \mathrm{ml}$ leupeptin, and 10 $\mu \mathrm{g} / \mathrm{ml}$ pepstatin. To analyze ECM proteins, $20-40 \mu \mathrm{g}$ of protein were boiled in sample buffer $(0.125 \mathrm{~m}$ Tris- $\mathrm{HCl}$ at $\mathrm{pH} 6.8,2 \% \mathrm{SDS}, 5 \%$ glycerol, $0.002 \%$ bromophenol blue, and 5\% 2-mercaptoethanol), applied to a $10 \%$ polyacrylamide gel, transferred to a polyvinylidene difluoride membrane (Millipore) or a nitrocellulose membrane (GE Healthcare Biosciences), and blocked with 3\% bovine serum albumin or 3\% skim milk in Tris-buffered saline containing $0.1 \%$ Tween 20 for $2 \mathrm{~h}$ at $25 \pm$ $2^{\circ} \mathrm{C}$. Membranes were then incubated with primary antibodies, including polyclonal rabbit anti-MMP-9 (1:1000 dilution; AB19016; Millipore Bioscience Research Reagents), anti-MMP-2 (1:1000 dilution; AB809; Millipore Bioscience Research Reagents), anti-BDNF (1:2000 dilution; SC-546; Santa Cruz Biotechnology), anti-laminin (1:2000 dilution, L9393; Sigma-Aldrich), anti- $\beta$-dystroglycan (1:2000 dilution, NCL- $\beta$ DG; Novocastra Laboratories), anti-neural cell adhesion molecular (NCAM, 1:2000 dilution, 556324; BD Biosciences), and anti- $\beta$-actin (1: 2000, A5441; Sigma-Aldrich) antibodies. After washing, blots were incubated with horseradish peroxidase-conjugated anti-rabbit or mouse secondary antibodies at a 1:2000 dilution (Kirkegaard and Perry Laboratories). Immunoreactive materials on the membrane were detected using enhanced chemiluminescence Western blotting detection reagents (GE Healthcare Biosciences) and exposed to x-ray film. The band intensities of the film were analyzed using densitometry. Mature BDNF (rBDNF; SE-546, Enzo Life Sciences) and pro-BDNF (Alomone Labs) were used as positive controls on Western blots.

In situ zymography. Mice were intracardially perfused with cold saline before being frozen at $-80^{\circ} \mathrm{C}$ using O.C.T. compound (Sakura Finetechnical). The brains were sectioned at a thickness of $20 \mu \mathrm{m}$ in a cryostat. We adapted a previously published in situ zymography method to localize net gelatinolytic activity in brain sections (Szklarczyk et al., 2002). Unfixed sections were incubated for $24 \mathrm{~h}$ at $37^{\circ} \mathrm{C}$ in a humid dark chamber with reaction buffer containing $0.5 \mathrm{~m}$ Tris- $\mathrm{HCl}$ ( $\mathrm{pH}$ 7.6), $1.5 \mathrm{M} \mathrm{NaCl}, 50 \mathrm{~mm} \mathrm{CaCl}_{2}, 2 \mathrm{~mm}$ 
$\mathrm{NaN}_{3}$, and $100 \mu \mathrm{g} / \mathrm{ml}$ intramolecularly quenched FITC-labeled DQ-gelatin (Invitrogen). After incubation, sections were washed in PBS and mounted on slides. Samples were observed with a FITC filter, and the images were analyzed using an AXIOVISION 3.0 system (Carl Zeiss). Cleavage of the FITC moiety by tissue gelatinases results in fluorescence that is representative of net proteolytic activity. Sections incubated without DQ-gelatin were not fluorescent.

Double immunostaining. Polyclonal rabbit anti-MMP-9 antibodies (FITC or Rhod, 1:500 dilution; ab16306; Abcam), monoclonal mouse anti-neuron-specific nuclear antigen (NeuN) antibodies (FITC, 1:200 dilution; MAB377; Millipore Bioscience Research Reagents) and antiglial fibrillary acidic protein (GFAP) antibodies (Rhod, 1:3000 dilution; G3893; Sigma-Aldrich) served as primary antibodies. Affinity-purified FITC-conjugated goat anti-rabbit IgG and rhodamine-conjugated goat anti-mouse IgG were used as secondary antibodies. Samples were observed with an AXIOVISION 3.0 system (Carl Zeiss).

Statistical analysis. All data are expressed as means \pm SE. Statistical significance was determined using Student's $t$ test for comparisons of two groups, one-way or two-way ANOVA for multigroup comparisons, and repeated-measures ANOVA. Bonferroni's test was used for post hoc comparison when the $F$ value was significant $(p<0.05)$.

\section{Results}

\section{Repeated administration of PTZ} induced MMP-9 expression in the hippocampi of kindled and cognitively impaired mice

Mice administered a single PTZ dose (20-40 mg/kg) exhibited ear and facial twitching (Stage 1 seizure) or, at times, convulsive twitching axially through the body (Stage 2 seizure) (Fig. 1A). PTZ at a dose of $60 \mathrm{mg} / \mathrm{kg}$ induced a seizure characterized by tonic convulsion, jumping, and wild running (Stage 4 or 5 ). On the other hand, repeated administration of PTZ at a dose of $40 \mathrm{mg} / \mathrm{kg}$ produced chemical kindling, a phenotype reflected by a progressive increase in the seizure score (Stage 4 or 5 ) (Fig. $1 B ; F_{(1,12)}=32.0, p<0.05$, repeated-measures ANOVA). To assess learning and memory, we used a conditioned fear memory test that associated a contextual stimulus (conditioned experimental chamber stimulus) with an electric foot shook (unconditioned stimulus); the mice were subjected to the test $24 \mathrm{~h}$ after the final PTZ dose. Compared with control mice, kindled mice, but not mice treated with a single PTZ injection (60 $\mathrm{mg} / \mathrm{kg}$ ), showed less freezing behavior in response to the conditioned experimental chamber stimulus, indicating impaired hippocampal-dependent memory in the kindled mice (Fig. $1 C$; $F_{(2,24)}=6.77, p<0.05$, one-way ANOVA).

Repeated PTZ treatment increased MMP-9 expression in the hippocampus $2 \mathrm{~h}$ after the final PTZ dose (Fig. $2 B$; $p<0.05, t$ test), and the increased MMP-9 levels were maintained until at least $24 \mathrm{~h}$ after the final dose (Fig. $2 C$; $p<0.05, t$ test). On the other hand, hippocampal MMP-9 levels were not affected in mice that showed convulsive seizures in response to a single PTZ dose of $60 \mathrm{mg} / \mathrm{kg}$ (Fig. $2 A ; p>0.05, t$ test). Note that all of the groups showed similar hippocampal MMP-2 levels.
A

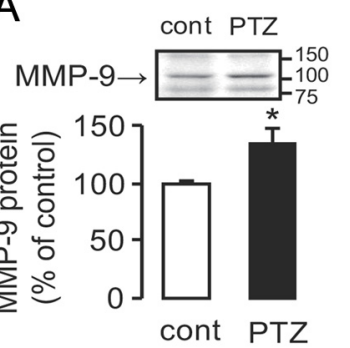

B
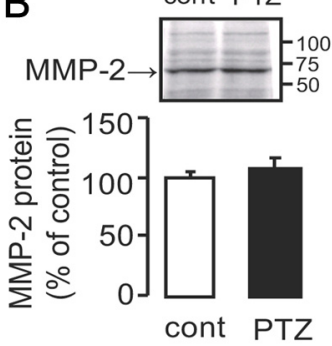

C MMP-9 (Green)
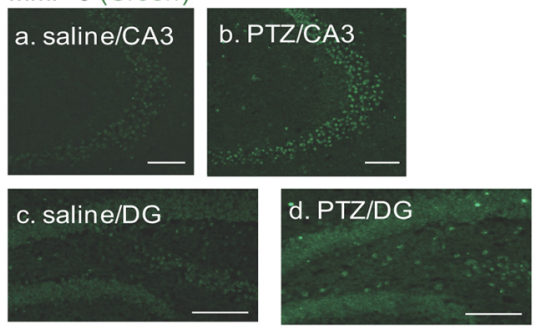

E

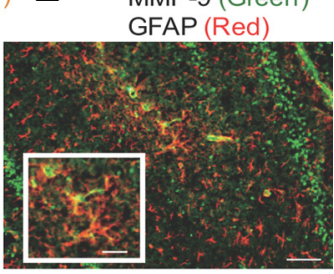

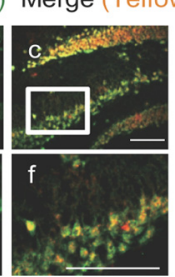

MMP-9 (Green)

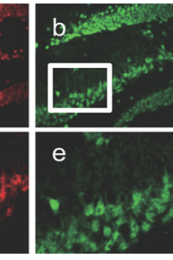

Figure 3. Changes in MMP-9 $(\boldsymbol{A})$ and MMP-2 $(\boldsymbol{B})$ protein levels after repeated PTZ treatment in the mouse hippocampus. Mice
were administered PTZ at least 11 times at a dose of $40 \mathrm{mg} / \mathrm{kg}$ and killed $24 \mathrm{~h}$ after the final dose. Control (Cont) mice were administered saline. Values are means $\pm \mathrm{SE}(n=5-6$ for $\boldsymbol{A} ; n=4$ for $\boldsymbol{B})$. ${ }^{*} p<0.05$ versus control group. $\boldsymbol{C}-\boldsymbol{E}$, Representative hippocampus for MMP-9 (red, Da, Dd) and NeuN (green, D $\boldsymbol{b}, \boldsymbol{D} \boldsymbol{e})$, or MMP-9 (green, $\boldsymbol{E}$ ) and GFAP (red, $\boldsymbol{E}$ ) is shown. Scale bars, 100

Net proteolytic activity in subregions of the hippocampus of MMP-2 $2^{(-1-)}$ mice after repeated PTZ treatment

We used in situ zymography to analyze changes in the spatial profile of hippocampal gelatinase activity following repeated PTZ treatment. Brain sections were incubated with gelatin conjugated to a quenched fluorescence dye, which, when cleaved by gelatinase, results in increased fluorescence. Previous experiments showed that this fluorescent signal was completely inhibited by the zinc chelator phenanthroline, a broad-spectrum MMP inhibitor, indicating that the fluorescence was associated with net MMP activity (Mizoguchi et al., 2007a, 2009). Because we used MMP- $2^{(-/-)}$mice in this study, the increased fluorescence reflected MMP-9 activity. Two hours after the final PTZ dose (40 $\mathrm{mg} / \mathrm{kg}$ ), an intense signal was observed in the hippocampus (Fig. $2 D a, D d)$. Net MMP-9 activity markedly increased in the DG (Fig. $2 D b, D e$ ) and CA3 (Fig. $2 D c, D f$ ) of the hippocampus in the group repeatedly treated with PTZ compared with the salinetreated group.

\section{Repeated PTZ treatment increased MMP-9 protein} expression in the brain

Next, we examined MMP-9 protein levels in the hippocampi of the kindled mice. Western blot analysis indicated that hippocampal levels of MMP-9 increased $2 \mathrm{~h}$ after repeated PTZ treatment compared with the level detected in the saline-treated group (Fig. $3 A ; p<0.05, t$ test). MMP-2 protein levels were not affected by repeated PTZ treatment (Fig. $3 B ; p>0.05, t$ test). 

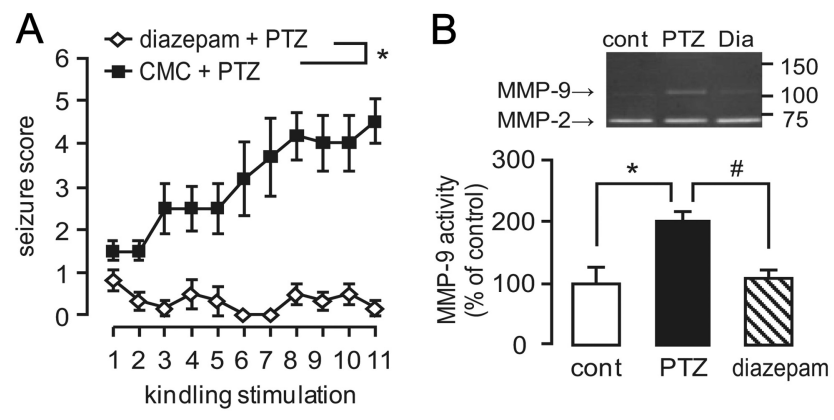

Figure 4. Effects of diazepam on kindled seizure (A) and MMP-9 activity $(\boldsymbol{B})$ evoked by repeated PTZ treatment. $A$, Mice were administered diazepam at a dose of $1 \mathrm{mg} / \mathrm{kg}$ or CMC 30 min before each PTZ dose. Values are means $\pm \mathrm{SE}(n=6) .{ }^{*} p<0.05$ versus $C M C+$ PTZ. $\boldsymbol{B}$, Mice were killed $2 \mathrm{~h}$ after the final PTZ dose. Values are means \pm SE $(n=5-12) .{ }^{*} p<0.05$ versus cont. $\# p<0.05$ versus PTZ. Dia, Diazepam.

To determine which cell types expressed MMP-9 following repeated PTZ treatment, we performed double immunostaining for MMP-9 and the neuronal marker NeuN (Fig. 3D) or the astroglial marker GFAP (Fig. 3E). In the PTZ-treated group, stronger MMP-9-specific signals were observed in the DG and CA3 of the hippocampus compared with the saline-injected group (Fig. $3 \mathrm{Cb}, \mathrm{Cd}$ compared with $3 \mathrm{Ca}, \mathrm{Cc}$ ). Most immunoreactivity in the control and PTZ-treated groups was observed in NeuN-positive cells (Fig. 3C,Dc,Df), suggesting that MMP-9 was expressed in neurons. Immunosignals were also observed in GFAP-positive cells in the hippocampus (Fig. 3E). These results indicate that repeated PTZ treatment induces MMP-9 expression in both neuronal and glial cells in the hippocampus.

\section{Diazepam inhibited the kindled seizures and MMP-9 expression induced by repeated PTZ treatment}

We examined whether diazepam, which is used to treat epilepsy, inhibited hippocampal MMP-9 expression in kindled mice. Pretreatment with diazepam significantly suppressed the development of PTZ-induced kindled seizure (Fig. $4 A ; F_{(1,10)}=59.6, p<0.05$, repeated two-way ANOVA), and inhibited MMP-9 expression in the hippocampi of kindled mice (Fig. $4 B ; F_{(2,18)}=8.50, p<0.05$, one-way ANOVA). Diazepam had little effect on MMP-2 expression in the hippocampus.

\section{Pretreatment with MK-801 inhibited PTZ-induced kindled seizure and hippocampal MMP-9 expression}

Pretreating rats with NMDA receptor antagonists at doses that do not have a marked anticonvulsant effect reportedly prevents epileptogenesis in kindling, pilocarpine, and kainate models of limbic seizure (Ormandy et al., 1989; Stafstrom et al., 1997). Interestingly, MMP-9 expression is induced via NMDA receptor signaling (Meighan et al., 2006; Nagy et al., 2006; Tian et al., 2007). Therefore, we investigated the effects of MK-801 on PTZ-induced increases in MMP-9 expression and kindled seizure. Pretreatment with MK-801 significantly suppressed the development of kindling (Fig. 5A; $F_{(1,9)}=14.3, p<0.05$, repeated two-way ANOVA) and inhibited MMP-9 expression in the hippocampus (Fig. $5 B ; F_{(2,9)}=8.60, p<$ 0.05 , one-way ANOVA), suggesting that NMDA receptors are involved in these processes in vivo.

\section{MMP-9 contributed to PTZ-induced development of kindled seizure}

We investigated the role for MMP-9 in PTZ-induced kindled seizure using MMP- $9^{(-/-)}$mice. No difference in the severity of tonic sei-
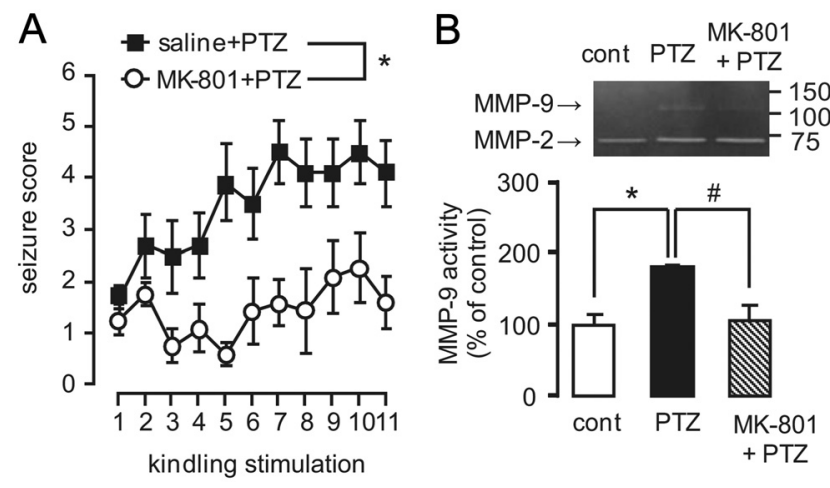

Figure 5. Effects of MK-801 on kindled seizure $(\boldsymbol{A})$ and MMP-9 activity $(\boldsymbol{B})$ evoked by repeated PTZ treatment. $A$, Mice were administered MK-801 at a dose of $0.1 \mathrm{mg} / \mathrm{kg}$ or saline 30 min before each PTZ dose. Values are means $\pm \mathrm{SE}(n=5-6) .{ }^{*} p<0.05$ versus saline $+\mathrm{PTZ}$. $\boldsymbol{B}$, Mice were killed $2 \mathrm{~h}$ after the final PTZ dose. Values are means $\pm \mathrm{SE}(n=4)$. ${ }^{*} p<0.05$ versus cont. \#p $<0.05$ versus PTZ.
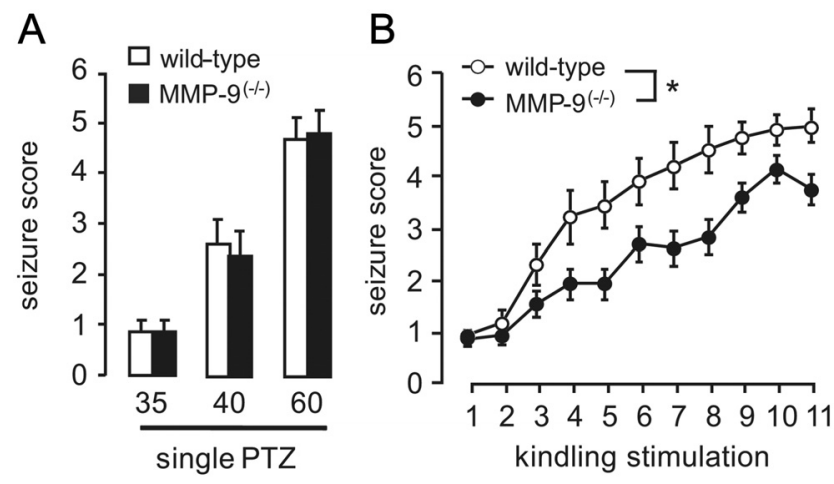

Figure 6. Seizure and kindling in MMP- $9^{(-1-)}$ mice administered PTZ once $(\boldsymbol{A})$ or repeatedly $(\boldsymbol{B})$. $\boldsymbol{A}$, Mice received a single injection of PTZ at doses of 35,40, or $60 \mathrm{mg} / \mathrm{kg}$. Values represent means $\pm \mathrm{SE}(n=5)$. $\boldsymbol{B}$, Mice were administered PTZ 11 times at a dose of $35 \mathrm{mg} / \mathrm{kg}$. Values are means $\pm \mathrm{SE}(n=13) .{ }^{*} p<0.05$ versus wild-type mice.

zure induced by single PTZ treatment (35-60 mg/kg) was observed between wild-type and MMP-9 ${ }^{(-1-)}$ mice (Fig. $6 A$ ). As shown in Figure $6 B$, repeated PTZ treatment at a dose of $35 \mathrm{mg} / \mathrm{kg}$ induced kindled seizure in wild-type mice. Under these conditions, PTZtreated MMP-9 ${ }^{(-1-)}$ mice showed a marked delay in development of kindling, although progression of kindled seizure was eventually observed (Fig. $6 B ; F_{(1,24)}=6.11, p<0.05$, repeated two-way ANOVA). These results demonstrate that deletion of the MMP-9 gene attenuated PTZ-induced kindled seizure.

Altered BDNF maturation in the hippocampi of kindled mice BDNF is associated with mossy fiber sprouting in the hippocampus. Extracellular BDNF stimulates TrkB receptors in the hilar segment of mossy fibers, inducing axonal branching and potentially establishing hyperexcitable dentate circuits (Koyama et al., 2004). Notably, BDNF is a substrate of MMP (Lee et al., 2001; Ethell and Ethell, 2007). We used Western blotting to confirm that mature BDNF formed when recombinant pro-BDNF was incubated with recombinant MMP-9 in zymography incubation buffer for $20 \mathrm{~h}$ at $37^{\circ} \mathrm{C}$ (data not shown).

Repeated PTZ treatment increased protein and mRNA levels of BDNF in the hippocampi of kindled mice as described below, whereas protein levels of other substrates for MMP, such as laminin (Gu et al., 2005), $\beta$-dystroglycan (Michaluk et al., 2007), and NCAM (Hübschmann et al., 2005), did not change (Table 1). In fully kindled 
Table 1. No changes in laminin, $\beta$-dystroglycan, and NCAM protein after repeated PTZ treatment in the hippocampus of mice

\begin{tabular}{|c|c|c|c|c|c|c|c|}
\hline \multirow[b]{2}{*}{ Group } & \multicolumn{2}{|c|}{$\operatorname{laminin}(n=4)$} & \multicolumn{2}{|c|}{$\beta$-dystroglycan $(n=8)$} & \multicolumn{3}{|c|}{ NCAM $(n=8)$} \\
\hline & $\alpha 1$ chain & $\beta 1 \gamma 1$ chain & $30 \mathrm{kDa}$ & $43 \mathrm{kDa}$ & $120 \mathrm{kDa}$ & $140 \mathrm{kDa}$ & $180 \mathrm{kDa}$ \\
\hline Control & $100 \pm 9.0$ & $100 \pm 9.6$ & $100 \pm 7.1$ & $100 \pm 6.3$ & $100 \pm 6.4$ & $100 \pm 7.8$ & $100 \pm 6.1$ \\
\hline Repeated PTZ & $79.2 \pm 2.6$ & $87.4 \pm 4.7$ & $82.0 \pm 8.5$ & $97.9 \pm 6.4$ & $80.9 \pm 9.6$ & $89.5 \pm 6.9$ & $84.4 \pm 6.9$ \\
\hline
\end{tabular}

Mice were given PTZ at a dose of $40 \mathrm{mg} / \mathrm{kg} 11$ times and killed $24 \mathrm{~h}$ after the final administration. Control animals were given saline. Values represent the mean $\pm \mathrm{SE}(n=4-8)$.

MMP-9 ${ }^{(-/-)}$mice that received 11 PTZ injections, BDNF mRNA levels in the hippocampus were significantly elevated compared with wild-type mice $6 \mathrm{~h}$ after the final PTZ dose (Fig. 7A; gene, $F_{(1,16)}=0.78$, $p>0.05$; drug treatment, $F_{(1,16)}=7.34, p<$ 0.05 ; interaction, $\left.F_{(1,16)}=0.82, p>0.05\right)$. Similarly, increased levels of mature BDNF protein were observed in the hippocampi of kindled wild-type and MMP- $9^{(-/-)}$mice, with no significant differences between the two groups (Fig. $7 B, C$; gene, $F_{(1,20)}=0.79$, $p>0.05$; drug treatment, $F_{(1,20)}=11.6, p<$ 0.05 ; interaction, $\left.F_{(1,20)}=0.22, p>0.05\right)$. The ratio of mature BDNF to pro-BDNF also increased in kindled wild-type and MMP- $9^{(-/-)}$mice, with no significant differences between the two groups (Fig. $7 C$; gene, $F_{(1,20)}=0.02, p>0.05$; drug treatment, $F_{(1,20)}=6.03, p<0.05$; interaction, $\left.F_{(1,20)}=0.01, p>0.05\right)$. Comparisons of results from saline-treated wild-type and MMP- $9^{(-/-)}$mice revealed no significant differences in mature BDNF levels or the ratio of mature BDNF to pro-BDNF $(p>0.05)$.

Interestingly, on Day 5 of repeated PTZ treatments-at which point, kindling had not yet fully developed (Fig. 6B)-mature BDNF protein levels increased in the hippocampi of wild-type mice $(p<0.05)$, but not MMP-9 ${ }^{(-/-)}$mice (Fig. $7 D, E$; drug treatment, $F_{(1,16)}=48.2, p<0.05$; gene, $F_{(1,16)}=23.3, p<0.05$; interaction, $F_{(1,16)}=$ $16.5, p<0.05)$. The ratio of mature BDNF to pro-BDNF increased in kindled wildtype mice $(p<0.05)$, with significant differences between PTZ-treated wild-type mice and MMP-9 ${ }^{(-1-)}$ mice (Fig. $7 E$; drug treatment, $F_{(1,16)}=13.5, p<0.05$; gene, $F_{(1,16)}=$ 12.9, $p<0.05$; interaction, $F_{(1,16)}=5.98$, $p<0.05)$. No differences were noted between saline-treated wild-type mice and saline-treated MMP- $9^{(-/-)}$mice in mature $\mathrm{BDNF}$ levels or the ratio of mature BDNF to pro-BDNF $(p>0.05)$. Similar changes in the levels of mature BDNF were observed when BDNF levels were analyzed $24 \mathrm{~h}$ after the final PTZ treatment (data not shown). These results suggest that MMP-9 increases mature BDNF levels in response to repeated PTZ injections, which may contribute to kindling development.

Effects of TrkB-Fc and pro-BDNF on kindling development in MMP-9 ${ }^{(-/-)}$mice

To further examine the relationship between MMP-9 and proBDNF maturation in PTZ-induced kindling, we investigated ef-
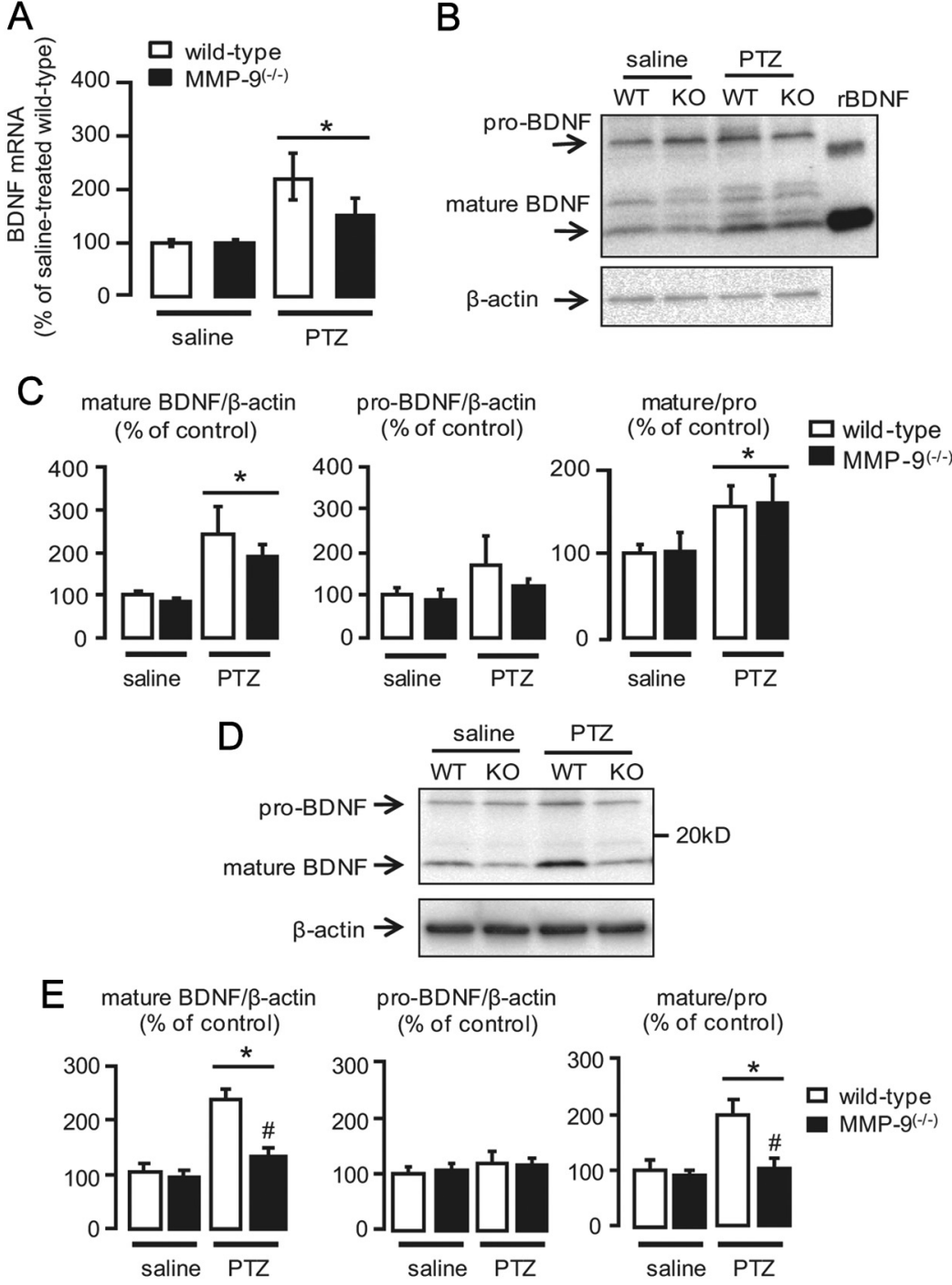

Figure 7. BDNFmRNA and mature BDNF protein expression in the mouse hippocampus. $\boldsymbol{A}-\boldsymbol{C}$, Mice were administered PTZ 11 times at a dose of $35 \mathrm{mg} / \mathrm{kg}$ and killed $6 \mathrm{~h}$ after the final dose. Control animals are saline-treated wild-type mice. Values are means $\pm \operatorname{SE}(n=5-6)$. ${ }^{*} p<0.05$ versus the saline-treated group. $\boldsymbol{B}, \boldsymbol{D}$, Representative images of Western blots of samples obtained after 11 or 5 PTZ doses, respectively. Mature BDNF (rBDNF) was used as a positive control. WT: wild-type mice. KO: MMP-9 ${ }^{(-/-)}$mice. $\boldsymbol{D}, \boldsymbol{E}$, Mice were administered PTZ five times at a dose of $35 \mathrm{mg} / \mathrm{kg}$ and killed $6 \mathrm{~h}$ after the final dose. Control animals are saline-treated wild-type mice. Values are means $\pm \mathrm{SE}(n=5)$. ${ }^{*} p<0.05$ versus saline-treated group. $\# p<0.05$ versus wild-type mice (PTZ).

fects of TrkB-Fc—a BDNF scavenger (Rex et al., 2007; Zhou et al., 2010, 2011) — and pro-BDNF on the development of kindling in MMP- $9^{(-/-)}$mice. In a preliminary study, implanting guide cannula into the right ventricle or hippocampal DG increased the sensitivity of mice to PTZ. Accordingly, the PTZ dose was reduced to $25 \mathrm{mg} / \mathrm{kg}$, which caused the animals to exhibit seizures with a score of 1 .

Compared with wild-type mice, PTZ-treated MMP-9 ${ }^{(-/-)}$ mice that received intraventricular injections of $\operatorname{IgG}_{1}-\mathrm{Fc}$ showed a marked delay in the development of kindling (Fig. 


\section{A wild-type}

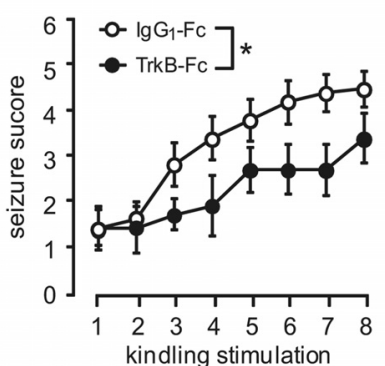

\section{C wild-type}

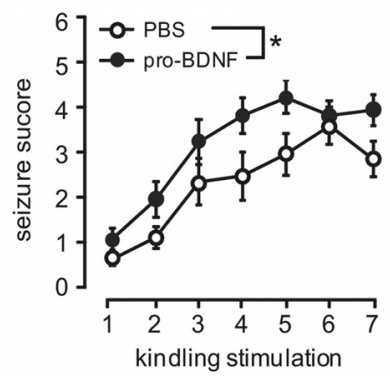

\section{B $\underline{M M P-9(--)}$}

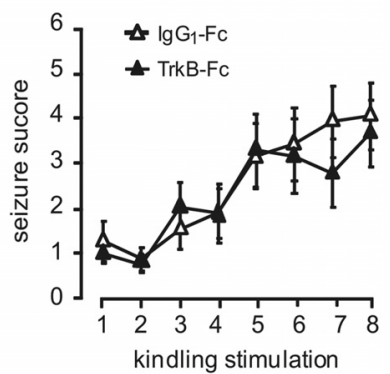

D $M M P-9^{(-1-)}$

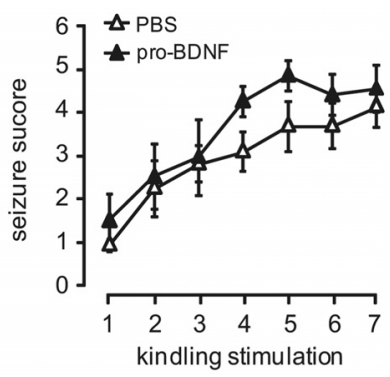

Figure 8. Effects of TrkB-Fc and pro-BDNF on PTZ-induced kindling in wild-type and MMP$9^{(-l-)}$ mice. $A, B$, Mice received microinjections of TrkB-Fcor lg $G_{1}-F c$ into the right ventricle 30 min before each PTZ treatment $(25 \mathrm{mg} / \mathrm{kg})$. Values are means \pm SE $(n=10$ for $\boldsymbol{A} ; n=8$ for $\boldsymbol{B})$. ${ }^{*} p<0.05$ versus $\operatorname{lgG}_{1}-\mathrm{Fc}$-injected wild-type mice. $\boldsymbol{C}, \boldsymbol{D}$, Mice received microinjections of proBDNF or PBS bilaterally into the hippocampal DG 30 min before each PTZ treatment $(25 \mathrm{mg} / \mathrm{kg})$. Values are means $\pm \operatorname{SE}(n=8-10$ for $A ; n=7$ for $\boldsymbol{B}) .{ }^{*} p<0.05$ versus PBS-injected wild-type mice.

$8 A, B ; F_{(1,16)}=4.73$, based on repeated two-way ANOVA). Pretreating the right ventricle with TrkB-Fc significantly suppressed the development of kindling in wild-type mice (Fig. $8 A$; group, $F_{(1,18)}=6.57, p<0.05$; stimulation, $F_{(7,126)}=10.45, p<0.05$; interaction, $F_{(7,126)}=1.07, p>0.05$, based on repeated two-way ANOVA), but had no effect in MMP- $9^{(-/-)}$mice (Fig. $8 B$; group, $F_{(1,14)}=0.10, p>0.05$; stimulation, $F_{(7,98)}=10.7, p<$ 0.05 ; interaction, $F_{(6,84)}=0.45, p>0.05$, based on repeated two-way ANOVA). On the other hand, bilateral microinjections of pro-BDNF into the hippocampal DG before each PTZ treatment significantly enhanced kindling development in wild-type mice (Fig. 8C; group, $F_{(1,16)}=6.50, p<0.05$; stimulation, $F_{(6,96)}=$ 25.1, $p<0.05$; interaction, $F_{(6,96)}=0.71, p<0.05$, based on repeated two-way ANOVA), whereas the same treatment did not produce these effects in MMP-9 $9^{(-/-)}$mice (Fig. $8 D$; group, $F_{(1,12)}=2.27, p>0.05$; stimulation, $F_{(6,72)}=11.26, p<0.05$; interaction, $F_{(6,72)}=0.34, p>0.05$, based on repeated two-way ANOVA). These results suggest that MMP-9 contributes to the development of PTZ-induced kindling seizure, possibly by converting pro-BDNF to mature BDNF in the hippocampus.

\section{Discussion}

In the present study, we demonstrated that kindling progression results in persistently increased MMP-9 protein expression and activity in the mouse hippocampus, whereas acute convulsion had little effect on this enzyme. Recent studies have linked MMPs to various pathologic conditions in the central nervous system, including ischemia, multiple sclerosis, Parkinson's disease, malignant glioma, Alzheimer's disease, and epilepsy. Interestingly, some evidence suggests that, in addition to its known extracellular role in macromolecule degradation, MMP may mediate apo-

ptotic and/or necrotic cell death (Jourquin et al., 2003; Kim et al., 2009) and synaptic plasticity (Tian et al., 2007; Wilczynski et al., 2008; Takács et al., 2010). The gelatinases MMP-2 and MMP-9 are initially expressed as inactive proenzymes that are cleaved to their active forms after they are released from cells (Van den Steen et al., 2002), allowing these proteases to regulate the levels of extracellular substrates. Our data showed that repeated treatment with PTZ led to kindling and cognitive impairment, which was accompanied by increased MMP-9 expression in the hippocampus. Additionally, we demonstrated that MMP-9 was expressed in hippocampal neuronal and glial cells in the kindled mice.

A previous study revealed that MMP-9 mRNA levels increased in response to neuronal depolarization in the rat hippocampus (Rylski et al., 2009). After seizure in kainic acid-treated rats, MMP-9 mRNA is transported to dendrites and synapses in the hippocampal DG (Konopacki et al., 2007). Our findings are consistent with these previous reports, suggesting that MMP-9 from astrocytes and/or neurons may contribute to PTZ-induced epileptogenesis and kindling seizure. On the other hand, some of our findings are not consistent with previous reports. For instance, a prominent increase in MMP-9 mRNA levels was observed in rats $2 \mathrm{~h}$ after a single $50 \mathrm{mg} / \mathrm{kg}$ PTZ dose (Rylski et al., 2009), and MMP-9 activity increased as early as $5 \mathrm{~min}$ after bicuculline treatment in mouse cortical cultures (Michaluk et al., 2007). More detailed examination of temporal changes and species differences in MMP-9 expression after single and repeated PTZ injection may help explain these discrepant results.

Pretreatment with MK-801 inhibited the PTZ-induced increase in MMP-9 expression and kindling, indicating that these events are associated with activation of NMDA receptors in this model (Fig. 5). In fact, an NMDA receptor antagonist completely prevented PTZ-induced convulsions and kindling (Giorgi et al., 1991), and excessive levels of synaptic glutamate and persistent influx of $\mathrm{Ca}^{2+}$ through NMDA receptors are considered major causes of epileptogenesis (Chen et al., 2007). In addition, the expression and activity of MMP-9 depend on NMDA receptor activation and are associated with LTP development (Meighan et al., 2006; Nagy et al., 2006). Activation of NMDA receptors leads to MMP-mediated modification of cell adhesion molecules and the development of dendritic spines (Tian et al., 2007). Our results suggest that MMP-9 expression and activity are regulated by repetitive activation of NMDA receptors, which may result in remodeling of neuronal circuits, epileptogenesis, and the development of kindling.

Dendritic spine morphology and synaptic potentiation are dynamically modulated by ECM proteins and cell-surface proteins with which they interact. This has led to the idea that ECM remodeling has an important role in synaptic plasticity. Indeed, evidence suggests that MMP-9 expression is upregulated and the protein becomes proteolytically active during the maintenance phase of LTP at CA3-CA1 synapses in the hippocampus (Nagy et al., 2006; Bozdagi et al., 2007). Similar findings have been recently reported for the rat prefrontal cortex (Okulski et al., 2007). These reports suggest a role for MMP-9 in neuronal plasticity, a concept supported by our findings in PTZ-induced kindled seizure. Marked suppression of the progression of kindled seizure induced by repeated PTZ treatment was observed in MMP-9 ${ }^{(-/-)}$ mice compared with wild-type mice (Fig. $6 B$ ). We showed that mossy fiber sprouting induced by repeated PTZ treatment was reduced in MMP- $9^{(-/-)}$mice compared with wild-type mice whose strain were FVB/N (data not shown), suggesting that increased hippocampal MMP-9 activity is associated with the sprouting of mossy fibers. These observations agree with recent 
findings showing that the synaptic pool of MMP-9 is critical for the mechanisms that underlie seizure development (Wilczynski et al., 2008). Similarly, degradation of laminin by tissue plasminogen activator (tPA) directly affects the dynamics of dendritic spine development (Oray et al., 2004), and tPA/plasmin regulates seizure-induced hippocampal mossy fiber outgrowth via a proteoglycan substrate (Wu et al., 2000). Accordingly, extracellular proteolytic systems, including MMP-9 and tPA, may play critical roles in aberrant synaptogenesis associated with epileptic seizure. PTZ-induced kindling may be aggravated through synaptic transformation, including mossy fiber sprouting induced by prolonged MMP-9 activation.

BDNF, a member of the neurotrophin family, plays an important role in the survival, differentiation, and growth of many types of neurons (Chao, 2003). BDNF has also been implicated as a potent morphoregulator that controls axon branching and activity-dependent refinement of synapses (Cabelli et al., 1995; Horch et al., 1999). Extracellular BDNF stimulates TrkB receptors on the hilar segment of the mossy fiber to induce axonal branching, which may create hyperexcitable dentate circuits (Koyama et al., 2004). We previously showed that BDNF contributes to nitric oxide-dependent plastic changes in neuronal excitability and epileptogenesis during kindling induced by PTZ (Han et al., 2000). These previous studies suggest that BDNF plays an etiologic role in epileptogenesis and kindled seizure. A recent study showed that high-frequency neuronal activity controls the ratio of extracellular pro-BDNF to mature BDNF by regulating the secretion of extracellular proteases (Nagappan et al., 2009). Of particular note for the present results, proforms of neurotrophin are cleaved and activated by MMP (Lee et al., 2001; Sternlicht and Werb, 2001; Ethell and Ethell, 2007), and MMP-9 converts pro-BDNF to mature BDNF, resulting in TrkB activation (Hwang et al., 2005; Ethell and Ethell, 2007).

We have demonstrated that BDNF expression, and in particular levels of mature BDNF, increased in the hippocampus in response to PTZ-induced kindling. This finding agrees with a previous report showing that levels of mature BDNF increased after status epilepticus in rats, whereas pro-BDNF levels did not change until $72 \mathrm{~h}$ after status epilepticus (Unsain et al., 2008). Importantly, MMP-9 ${ }^{(-/-)}$mice showed reduced levels of mature BDNF during the early stage of kindling, which may explain slower kindling development in the mutant animals. During the later kindling stage, however, mature BDNF levels were similar in MMP-9 $9^{(-/-)}$and wild-type mice. Our findings suggest that MMP-9 plays a role in kindling development by converting proBDNF to mature BDNF in the hippocampus, whereas other factors mediate BDNF maturation during the later kindling stage. This may explain why the seizure response curves for MMP$9^{(-/-)}$and wild-type mice differ more at the early stage than at the later stage of kindling.

We also examined whether experimentally decreasing mature BDNF levels using the BDNF scavenger TrkB-Fc attenuated kindling or increasing pro-BDNF levels enhanced kindling in wildtype mice. In the experiment of pro-BDNF injection, kindling development was not delayed in MMP- $9^{(-1-)}$ mice following intrahippocampal PBS injections, whereas a significant delay was observed in MMP- $9^{(-/-)}$mice following intraventricular injections of $\operatorname{IgG}_{1}-\mathrm{Fc}$. The mechanisms underlying these findings are unclear, but may result from tissue damage caused by bilateral implantation of guide cannulae into the hippocampus. Under these conditions, the effects of TrkB-FC and pro-BDNF injections on PTZ-induced kindling were observed only in wild-type mice, but not MMP- $9^{(-/-)}$mice. These results likely reflect a relationship between MMP-9 expression and mature BDNF levels in the development of PTZ-induced kindling.

In conclusion, the present findings highlight the contribution of neural/glial MMP-9 to epileptogenesis via its activity on extracellular macromolecules, such as BDNF. Importantly, selective MMP-9 inhibitors may provide neuroprotective effects in patients with epilepsy.

\section{References}

Becker A, Grecksch G, Schröder H (1995) N omega-nitro-L-arginine methyl ester interferes with pentylenetetrazole-induced kindling and has no effect on changes in glutamate binding. Brain Res 688:230-232.

Bozdagi O, Nagy V, Kwei KT, Huntley GW (2007) In vivo roles for matrix metalloproteinase-9 in mature hippocampal synaptic physiology and plasticity. J Neurophysiol 98:334-344.

Cabelli RJ, Hohn A, Shatz CJ (1995) Inhibition of ocular dominance column formation by infusion of NT-4/5 or BDNF. Science 267:1662-1666.

Cavazos JE, Golarai G, Sutula TP (1991) Mossy fiber synaptic reorganization induced by kindling: time course of development, progression, and permanence. J Neurosci 11:2795-2803.

Cavazos JE, Das I, Sutula TP (1994) Neuronal loss induced in limbic pathways by kindling: evidence for induction of hippocampal sclerosis by repeated brief seizures. J Neurosci 14:3106-3121.

Chao MV (2003) Neurotrophins and their receptors: a convergence point for many signalling pathways. Nat Rev Neurosci 4:299-309.

Chen Q, He S, Hu XL, Yu J, Zhou Y, Zheng J, Zhang S, Zhang C, Duan WH, Xiong ZQ (2007) Differential roles of NR2A- and NR2B-containing NMDA receptors in activity-dependent brain-derived neurotrophic factor gene regulation and limbic epileptogenesis. J Neurosci 27:542-552.

Ethell IM, Ethell DW (2007) Matrix metalloproteinases in brain development and remodeling: synaptic functions and targets. J Neurosci Res 85:2813-2823.

Franklin KBJ, Paxinos G (1997) The mouse brain in stereotaxic coordinates. New York: Academic.

Giorgi O, Orlandi M, Geic M, Corda MG (1991) MK-801 prevents the decrease in 35S-TBPS binding in the rat cerebral cortex induced by pentylenetetrazole kindling. Brain Res Bull 27:835-837.

Goddard GV, McIntyre DC, Leech CK (1969) A permanent change in brain function resulting from daily electrical stimulation. Exp Neurol 25:295-330.

Gu Z, Cui J, Brown S, Fridman R, Mobashery S, Strongin AY, Lipton SA (2005) A highly specific inhibitor of matrix metalloproteinase-9 rescues laminin from proteolysis and neurons from apoptosis in transient focal cerebral ischemia. J Neurosci 25:6401-6408.

Han D, Yamada K, Senzaki K, Xiong H, Nawa H, Nabeshima T (2000) Involvement of nitric oxide in pentylenetetrazole-induced kindling in rats. J Neurochem 74:792-798.

Horch HW, Krüttgen A, Portbury SD, Katz LC (1999) Destabilization of cortical dendrites and spines by BDNF. Neuron 23:353-364.

Hübschmann MV, Skladchikova G, Bock E, Berezin V (2005) Neural cell adhesion molecule function is regulated by metalloproteinase-mediated ectodomain release. J Neurosci Res 80:826-837.

Hwang JJ, Park MH, Choi SY, Koh JY (2005) Activation of the Trk signaling pathway by extracellular zinc. Role of metalloproteinases. J Biol Chem 280:11995-12001.

Itoh T, Ikeda T, Gomi H, Nakao S, Suzuki T, Itohara S (1997) Unaltered secretion of $\beta$-amyloid precursor protein in gelatinase A (matrix metalloproteinases 2)-deficient mice. J Biol Chem 272:22389-22392.

Jourquin J, Tremblay E, Décanis N, Charton G, Hanessian S, Chollet AM, Le Diguardher T, Khrestchatisky M, Rivera S (2003) Neuronal activitydependent increase of net matrix metalloproteinase activity is associated with MMP-9 neurotoxicity after kainate. Eur J Neurosci 18:1507-1517.

Kim GW, Kim HJ, Cho KJ, Kim HW, Cho YJ, Lee BI (2009) The role of MMP-9 in integrin-mediated hippocampal cell death after pilocarpineinduced status epilepticus. Neurobiol Dis 36:169-180.

Konopacki FA, Rylski M, Wilczek E, Amborska R, Detka D, Kaczmarek L, Wilczynski GM (2007) Synaptic localization of seizure-induced matrix metalloproteinase-9 mRNA. Neuroscience 150:31-39.

Koyama R, Yamada MK, Fujisawa S, Katoh-Semba R, Matsuki N, Ikegaya Y (2004) Brain-derived neurotrophic factor induces hyperexcitable reentrant circuits in the dentate gyrus. J Neurosci 24:7215-7224.

Lee R, Kermani P, Teng KK, Hempstead BL (2001) Regulation of cell survival by secreted proneurotrophins. Science 294:1945-1948. 
Meighan SE, Meighan PC, Choudhury P, Davis CJ, Olson ML, Zornes PA, Wright JW, Harding JW (2006) Effects of extracellular matrix-degrading proteases matrix metalloproteinases 3 and 9 on spatial learning and synaptic plasticity. J Neurochem 96:1227-1241.

Michaluk P, Kolodziej L, Mioduszewska B, Wilczynski GM, Dzwonek J, Jaworski J, Gorecki DC, Ottersen OP, Kaczmarek L (2007) Betadystroglycan as a target for MMP-9, in response to enhanced neuronal activity. J Biol Chem 282:16036-16041.

Mizoguchi H, Yamada K, Mizuno M, Mizuno T, Nitta A, Noda Y, Nabeshima $\mathrm{T}$ (2004) Regulations of methamphetamine reward by extracellular signal-regulated kinase 1/2/ets-like gene-1 signaling pathway via the activation of dopamine receptors. Mol Pharmacol 65:1293-1301.

Mizoguchi H, Yamada K, Niwa M, Mouri A, Mizuno T, Noda Y, Nitta A, Itohara S, Banno Y, Nabeshima T (2007a) Reduction of methamphetamineinduced sensitization and reward in matrix metalloproteinase-2 and -9deficient mice. J Neurochem 100:1579-1588.

Mizoguchi H, Yamada K, Mouri A, Niwa M, Mizuno T, Noda Y, Nitta A, Itohara S, Banno Y, Nabeshima T (2007b) Role of matrix metalloproteinase and tissue inhibitor of MMP in methamphetamine-induced behavioral sensitization and reward: implications for dopamine receptor down-regulation and dopamine release. J Neurochem 102:1548-1560.

Mizoguchi H, Takuma K, Fukuzaki E, Ibi D, Someya E, Akazawa KH, Alkam T, Tsunekawa H, Mouri A, Noda Y, Nabeshima T, Yamada K (2009) Matrix metalloprotease- 9 inhibition improves amyloid beta-mediated cognitive impairment and neurotoxicity in mice. J Pharmacol Exp Ther 331:14-22.

Mizoguchi H, Ibi D, Takuma K, Toth E, Sato J, Itohara S, Nabeshima T, Yamada K (2010) Alterations of emotional and cognitive behaviors in matrix metalloproteinase-2 and -9-deficient mice. Open Behav Sci J 4:19-25.

Nagappan G, Zaitsev E, Senatorov VV Jr, Yang J, Hempstead BL, Lu B (2009) Control of extracellular cleavage of ProBDNF by high frequency neuronal activity. Proc Natl Acad Sci U S A 106:1267-1272.

Nagy V, Bozdagi O, Matynia A, Balcerzyk M, Okulski P, Dzwonek J, Costa RM, Silva AJ, Kaczmarek L, Huntley GW (2006) Matrix metalloproteinase-9 is required for hippocampal late-phase long-term potentiation and memory. J Neurosci 15:1923-1934.

Okulski P, Jay TM, Jaworski J, Duniec K, Dzwonek J, Konopacki FA, Wilczynski GM, Sánchez-Capelo A, Mallet J, Kaczmarek L (2007) TIMP-1 abolishes MMP-9-dependent long-lasting long-term potentiation in the prefrontal cortex. Biol Psychiatry 62:359-362.

Oray S, Majewska A, Sur M (2004) Dendritic spine dynamics are regulated by monocular deprivation and extracellular matrix degradation. Neuron 44:1021-1030.

Ormandy GC, Jope RS, Snead OC $3^{\text {rd }}$ (1989) Anticonvulsant actions of MK-801 on the lithium-pilocarpine model of status epilepticus in rats. Exp Neurol 106:172-180.

Pinel JP, Rovner LI (1978) Electrode placement and kindling-induced experimental epilepsy. Exp Neurol 58:335-346.

Racine RJ (1972) Modification of seizure activity by electrical stimulation. II. Motor seizure. Electroencephalogr Clin Neurophysiol 32:281-294.

Rex CS, Lin CY, Kramár EA, Chen LY, Gall CM, Lynch G (2007) Brainderived neurotrophic factor promotes long-term potentiation-related cytoskeletal changes in adult hippocampus. J Neurosci 27:3017-3029.

Rylski M, Amborska R, Zybura K, Michaluk P, Bielinska B, Konopacki FA, Wilczynski GM, Kaczmarek L (2009) JunB is a repressor of MMP-9 transcription in depolarized rat brain neurons. Mol Cell Neurosci 40:98-110.

Schröder H, Becker A, Lössner B (1993) Glutamate binding to brain membranes is increased in pentylenetetrazole-kindled rats. J Neurochem 60:1007-1011.

Shirayama Y, Chen AC, Nakagawa S, Russell DS, Duman RS (2002) Brain- derived neurotrophic factor produces antidepressant effects in behavioral models of depression. J Neurosci 22:3251-3261.

Stafstrom CE, Tandon P, Hori A, Liu Z, Mikati MA, Holmes GL (1997) Acute effects of MK801 on kainic acid-induced seizures in neonatal rats. Epilepsy Res 26:335-344.

Sternlicht MD, Werb Z (2001) How matrix metalloproteinases regulate cell behavior. Annu Rev Cell Dev Biol 17:463-516.

Suenaga N, Ichiyama T, Kubota M, Isumi H, Tohyama J, Furukawa S (2008) Roles of matrix metalloproteinase- 9 and tissue inhibitors of metalloproteinases 1 in acute encephalopathy following prolonged febrile seizures. J Neurol Sci 266:126-130.

Sutula T, He XX, Cavazos J, Scott G (1988) Synaptic reorganization in the hippocampus induced by abnormal functional activity. Science 239: $1147-1150$.

Szklarczyk A, Lapinska J, Rylski M, McKay RD, Kaczmarek L (2002) Matrixmetalloproteinase- 9 undergoes expression and activation during dendritic remodeling in adult hippocampus. J Neurosci 22:920-930.

Takács E, Nyilas R, Szepesi Z, Baracskay P, Karlsen B, Røsvold T, Bjørkum AA, Czurkó A, Kovács Z, Kékesi AK, Juhász G (2010) Matrix metalloproteinase- 9 activity increased by two different types of epileptic seizures that do not induce neuronal death: a possible role in homeostatic synaptic plasticity. Neurochem Int 56:799-809.

Tian L, Stefanidakis M, Ning L, Van Lint P, Nyman-Huttunen H, Libert C, Itohara S, Mishina M, Rauvala H, Gahmberg CG (2007) Activation of NMDA receptors promotes dendritic spine development through MMPmediated ICAM-5 cleavage. J Cell Biol 178:687-700.

Unsain N, Nuñez N, Anastasía A, Mascó DH (2008) Status epilepticus induces a TrkB to $p 75$ neurotrophin receptor switch and increases brainderived neurotrophic factor interaction with p 75 neurotrophin receptor: an initial event in neuronal injury induction. Neuroscience 154:978-993.

Van den Steen PE, Dubois B, Nelissen I, Rudd PM, Dwek RA, Opdenakker G (2002) Biochemistry and molecular biology of gelatinase B or matrix metalloproteinase-9 (MMP-9). Crit Rev Biochem Mol Biol 37:375-536.

Wilczynski GM, Konopacki FA, Wilczek E, Lasiecka Z, Gorlewicz A, Michaluk P, Wawrzyniak M, Malinowska M, Okulski P, Kolodziej LR, Konopka W, Duniec K, Mioduszewska B, Nikolaev E, Walczak A, Owczarek D, Gorecki DC, Zuschratter W, Ottersen OP, Kaczmarek L (2008) Important role of matrix metalloproteinase 9 in epileptogenesis. J Cell Biol 180:1021-1035.

Wu YP, Siao CJ, Lu W, Sung TC, Frohman MA, Milev P, Bugge TH, Degen JL, Levine JM, Margolis RU, Tsirka SE (2000) The tissue plasminogen activator (tPA)/plasmin extracellular proteolytic system regulates seizureinduced hippocampal mossy fiber outgrowth through a proteoglycan substrate. J Cell Biol 148:1295-1304.

Yajima Y, Narita M, Usui A, Kaneko C, Miyatake M, Narita M, Yamaguchi T, Tamaki H, Wachi H, Seyama Y, Suzuki T (2005) Direct evidence for the involvement of brain-derived neurotrophic factor in the development of a neuropathic pain-like state in mice. J Neurochem 93:584-594.

Yong VW, Power C, Forsyth P, Edwards DR (2001) Metalloproteinases in biology and pathology of the nervous system. Nat Rev Neurosci 2:502-511.

Zeng LH, Xu L, Rensing NR, Sinatra PM, Rothman SM, Wong M (2007) Kainate seizures cause acute dendritic injury and actin depolymerization in vivo. J Neurosci 27:11604-11613.

Zhang JW, Gottschall PE (1997) Zymographic measurement of gelatinase activity in brain tissue after detergent extraction and affinity-support purification. J Neurosci Methods 76:15-20.

Zhou LJ, Ren WJ, Zhong Y, Yang T, Wei XH, Xin WJ, Liu CC, Zhou LH, Li YY, Liu XG (2010) Limited BDNF contributes to the failure of injury to skin afferents to produce a neuropathic pain condition. Pain 148:148-157.

Zhou LJ, Yang T, Wei X, Liu Y, Xin WJ, Chen Y, Pang RP, Zang Y, Li YY, Liu XG (2011) Brain-derived neurotrophic factor contributes to spinal long-term potentiation and mechanical hypersensitivity by activation of spinal microglia in rat. Brain Behav Immun 25:322-334. 